DOI: https://doi.org/10.24127/ajpm.v9i1.2666

\title{
PENGARUH MODEL THINK PAIR SHARE BERBANTUAN MAPLE TERHADAP HASIL BELAJAR FUNGSI INVERS
}

\author{
Sondang Purnama Pakpahan ${ }^{1}$, Andy Sapta ${ }^{2 *}$ \\ ${ }^{1}$ Universitas Terbuka, Jakarta, Indonesia \\ ${ }^{2 *}$ Sekolah Tinggi Manajemen dan Informatika Royal, Kisaran, Indonesia \\ *Corresponding author. Jl. Prof.H.M.Yamin No.173 Kisaran Naga, Asahan, 21222, Sumatera Utara, Indonesia. \\ E-mail: $\quad$ sondangp@ecampus.ut.ac.id ${ }^{l)}$ \\ sapta@royal.ac.id $^{2 *}$
}

Received 29 January 2020; Received in revised form 25 March 2020; Accepted 29 March 2020

\begin{abstract}
Abstrak
Tujuan penelitian ini adalah untuk mengetahui pengaruh penggunaan model think pair share berbantuan maple terhadap hasil belajar mahasiswa pada materi fungsi invers. Penelitian ini menggunakan metode kuantitatif berbentuk quasi experiment. Populasi penelitian ini adalah mahasiswa STMIK Royal yang berjumlah 526 orang yang terkelompok menjadi 17 kelas. Penentuan kelas kontrol dan kelas eksperimen dengan cara teknik cluster random sampling. Sampel penelitian ini terdiri dari 64 siswa. Sampel penelitian ini terdiri dari 2 kelas meliputi satu kelas eksperimen (model pembelajaran think pair share berbantuan maple) terdiri dari 32 mahasiswa dan satu kelas kontrol (model pembelajaran student team achievement division) terdiri dari 32 mahasiswa. Instrument yang digunakan dalam penelitian ini adalah tes uraian sebanyak lima butir soal. Instrument tes telah diuji validitas dan reliabilitas sebelum diberikan kepada sampel. Hasil penelitian diperoleh bahwa $p$ value sebesar 0,003 $<0,005$ sehingga diperoleh bahwa terdapat perbedaan yang signifikan dengan probabilitas sebesar 0,05 pada hasil belajar fungsi invers antara mahasiswa pada kelas eksperimen dan siswa pada kelas kontrol. Pembelajaran matematika pada fungsi invers dengan menggunakan model think pair share berbantuan maple secara empiris terbukti dapat meningkatkan pemahaman mahasiswa pada materi fungsi invers.
\end{abstract}

Kata kunci: fungsi invers; maple; student teams achievement division; think pair share.

\begin{abstract}
The purpose of this study was to determine the effect of using maple assisted think pair share models on student learning outcomes in the inverse function material. This research uses a quantitative method in the form of a quasi-experiment. The population of this research is STMIK Royal students, amounting to 526 people who are grouped into 17 classes. Determination of the control class and the experimental class using the cluster random sampling technique. The research sample consisted of 64 students. The sample of this study consisted of 2 classes including one experimental class (maple assisted think pair share learning model) consisting of 32 students and one control class (student team achievement division learning model) consisting of 32 students. The instrument used in this study was a descriptive test of five items. The test instrument was tested for validity and reliability before being given to the sample. The results obtained that the p-value of $0.003<0.005$ so that it is obtained that there is a significant difference with a probability of 0.05 in the learning outcomes of inverse functions between students in the experimental class and students in the control class. Mathematics learning on inverse functions using empirically assisted maple pair to think models are proven to be able to improve students' understanding of the inverse function material.
\end{abstract}

Keywords: inverse function; maple; student team achievement division; think pair share.

\section{PENDAHULUAN}

Dosen sebagai salah satu komponen dalam proses pembelajaran sangat besar pengaruhnya. Proses pembelajaran di dalam kelas, dosen tidak hanya dituntut untuk bertugas merencanakan dan melaksanakan proses pembelajaran di kelas tetapi juga 
bertanggung jawab terhadap keberhasilan seluruh proses yang dilakukannya. Untuk mencapai keberhasilan tersebut, dosen harus mampu menerapkan model pembelajaran yang baik. (Dahari \& Hall, 2017) mengemukakan bahwa model pembelajaran yang dilaksanakan harus mampu membuat siswa dapat memahami pengetahuan yang ditransfer oleh guru secara praktis.

Pada kondisi yang terjadi saat ini, dalam pembelajaran banyak dosen yang hanya berperan sebagai pemberi informasi kepada mahasiswanya, namun informasi tersebut tidak sepenuhnya direspon oleh mahasiswa dengan aktif Hal ini terjadi dikarenakan banyak mahasiswa takut bertanya atau menanggapi informasi yang disampaikan oleh dosen, sehingga berdampak negatif terhadap hasil belajar mahasiswa (Sapta, 2018).

Dari hasil pengamatan yang dilakukan bahwa permasalahan yang selalu muncul dalam pembelajaran mata kuliah matematika diskrit adalah rendahnya hasil belajar mahasiswa. Rendahnya hasil belajar matematika diskrit disebabkan kurangnya minat mahasiswa untuk belajar matematika, mahasiswa selalu menganggap matematika sebagai ilmu sukar, dan sulit untuk memahami keabstrakannya, sehingga menimbulkan rasa takut dan tidak adanya minat mahasiswa dalam belajar matematika. (Sapta, 2018; Yorulmaz, Altintas, \& Sidekli, 2017) menyatakan bahwa proses pembelajaran dapat diikuti dengan baik dan menarik perhatian siswa ketika menggunakan metode pembelajaran yang sesuai dengan tingkat perkembangan siswa dan sesuai dengan materi pembelajaran. juga menuntut siswa untuk mampu berpikir logis, kritis, analisis, kreatif, dan mampu menciptakan kerjasama yang baik.
Dalam proses pembelajaran di kelas banyak siswa yang lemah dalam belajar matematika, ini tentu saja bisa menjadi kendala dalam proses pembelajaran (Sapta, Hamid, \& Syahputra, 2018). Peneliti lain mengemukakan dalam kegiatan pembelajaran sering dijumpai suatu masalah dimana saat mengerjakan soal matematika terlebih pada materi fungsi invers, terdapat perbedaan hasil jawaban antara siswa yang satu dengan siswa yang lain sehingga membuat siswa bingung untuk menentukan jawaban yang benar, hal ini juga membuat siswa kurang percaya diri terhadap jawaban yang diperolehnya untuk menyelesaikan masalah ini tentunya dibutuhkan waktu yang cukup lama (Susanti \& Lestari, 2019).

Penyebab lainnya adalah pembelajaran di kampus masih menggunakan metode pembelajaran yang konvensional dengan metode ceramah sebagai metode utama. Pembelajaran dengan metode konvensional menyebabkan masih dominannya dosen dalam proses pembelajaran dan kurangnya kreatifitas mahasiswa dalam memberikan alternatif jawaban dari suatu pertanyaan serta menjadikan mahasiswa pasif, karena mereka hanya duduk mendengarkan penjelasan dari dosen dan mencatat hal-hal yang dianggap penting. Penggunaan metode konvensional membuat mahasiswa cenderung pasif. Mahasiswa hanya mendengarkan penjelasan dari dosen dan digiring untuk menerima penjelasan dari dosen tanpa adanya usaha untuk mencari kebenaran dari kondisi yag ada (Sapta, Pakpahan, \& Sirait, 2019).

Diantara banyaknya model pembelajaran yang ada, salah satu model pembelajaran yang sering digunakan adalah model pembelajaran Think Pair Share (TPS). (Lestari, 
Samsuri, \& Adawiyah, 2017; Paryanti, 2015) Model pem-belajaran ini digunakan karena dianggap menyenangkan serta mampu meningkatkan aktifitas mahasiswa dalam pembelajaran, mahasiswa dapat saling berbagi informasi dan pengetahuan yang dimilikinya serta dapat menilai kesukaran suatu masalah. (Kusuma \& Maskuroh, 2018; Zuraida \& Karyati, 2018) Penggunaan model pembelajaran TPS ini selain mengaktifkan mahasiswa, merangsang keberanian mahasiswa juga memberi mahasiswa banyak waktu untuk berpikir dan saling berbagi informasi.

Media komputer dewasa ini telah memegang peran penting dalam proses pembelajaran. Jika dilihat dari perkembangan aplikasi komputer yang begitu pesat, maka dalam pembelajaran matematika penggunaan media software komputer sudah dapat dilaksanakan. Tetapi kenyataannya masih banyak dosen yang belum memanfaatkan software komputer sebagai alat bantu dalam pembelajaran. (Laswadi, 2015; Oktaviani, Santoso, \& Hiltrimartin, 2017; Pratama \& Ismiyati, 2019) Media software komputer dapat digunakan oleh dosen untuk membantu siswa dalam memahami matematika, dan dapat digunakan siswa untuk melihat hasil jawabannya setelah siswa menyelesaikan soal secara manual. Pembelajaran dengan menggunakan media komputer diyakini dapat merangsang minat siswa untuk mendapatkan hasil belajar lebih baik dan juga bisa membuat proses pembelajaran lebih menarik.

Untuk membuat situasi belajar lebih menyenangkan dan lebih interaktif, perlu dikolaborasikan dengan penggunaan media software dinamis yang dapat menimbulkan situasi belajar seperti yang diharapkan yaitu menyenangkan dan interaktif serta menarik untuk diikuti siswa. Salah satu aplikasi komputer yang dipakai untuk menyelesaikan permasalah tersebut adalah dengan menggunakan aplikasi maple. (Sapta, 2018; Tossavainen \& Faarinen, 2019) aplikasi matematika yang dapat digunakan dalam proses pembelajaran, demikian halnya dengan maple sehingga aplikasi ini dapat dijadikan alternatif pendampingan dalam proses pembelajaran. Maple juga memiliki fasilitas untuk membuat grafik dua dimensi dan tiga dimensi. Grafik yang dihasilkan dapat dipindahkan ke dokumen lain. Keuntungan lain dari maple adalah dapat mendukung pemrograman. Dengan demikian, program dalam bentuk fungsi baru untuk penggunaan khusus dapat dibuat.

Maple merupakan sebuah software komputasi matematika (simbolik) sangat tepat untuk dimanfaatkan dalam pendampingan dalam pembelajaran matematika, hal ini disebabkan karena kemudahan maple dalam membantu menyelesaikan soal-soal matematika khususnya pada materi fungsi invers. Penggunan aplikasi maple ini masalah seperti perbedaan jawaban yang terdapat antara siswa yang satu dengan yang lain juga dapat diselesaikan dengan cepat. Kolaborasi penggunaan model pembelajaran think pair share dengan maple diharapkan mampu membuat hasil belajar yang lebih baik bagi mahasiswa yang sedang mempelajari materi fungsi invers.

Berdasarkan kondisi yang ada dilakukan penelitian dengan tujuan untuk mengetahui hasil belajar mahasiswa dengan menerapkan model pembelajaran think pair share berbantuan maple pada mata kuliah matematika diskrit khususnya pada materi fungsi invers. Tujuan ini dianggap penting untuk dicapai selain 
untuk meningkatkan hasil belajar mahasiswa juga untuk lebih memperdayakan penggunakan information technology dalam pembelajaran.

\section{METODE PENELITIAN}

Penggunaan metode pada penelitian ini adalah metode kuantitatif berbentuk quasi eksperiment. Dalam penelitian ini diujicobakan suatu tindakan untuk mengetahui hubungan antara tindakan dengan unsur tertentu yang diukur. Perlakuan yang diberikan adalah pembelajaran matematika dengan menggunakan model think pair share berbantuan maple, sedangkan aspek yang diukur adalah hasil belajar mahasiswa pada materi fungsi invers. Dari kondisi yang ada, yang menjadi variabel bebas dalam penelitian ini adalah model pembelajaran think pair share berbantuan mpale (pada kelas eksperimen) dan model pembelajaran student team achievement division (pada kelas kontrol). Variabel terikat pada penelitian ini adalah hasil belajar mahasiswa pada materi fungsi invers.

Penelitian ini dilaksanakan Sekolah Tinggi Manajemen Informatika dan Komputer Royal (STMIK Royal) yang bertempat di kota Kisaran kabupaten Asahan provinsi Sumatera Utara. Waktu penelitian dilaksanakan pada semester ganjil Tahun Ajaran 2018/2019. Populasi penelitian ini adalah seluruh mahasiswa semester satu yang berjumlah 526 orang yang terkelompok menjadi 17 kelas. Untuk menentukan pemilihan kelas ekserimen dan kelas kontrol dilakukan secara acak dengan menggunakan teknik cluster random sampling. Sampel penelitian ini terdiri dari 2 kelas meliputi satu kelas eksperimen dan satu kelas kontrol. Masing-masing kelas terdapat sebanyak
32 mahasiswa sehingga total sampel sebanyak 64 siswa.

Guna mengetahui kelayakan dari kedua kelas penelitian, sebelumya dilakukan uji persyaratan data untuk memenuhi normalitas dan homogenitas. Instrumen yang digunakan dalam penelitian ini adalah dengan menggunakan tes uraian sebanyak 5 soal. Instrumen tes telah diuji validitas dan reliabitias.

Pada penelitian ini tes hasil belajar dilakukan sebanyak dua kali, yaitu sebelum pembelajaran (pretest) dan sesudah pembelajaran berlangsung (postest). Pretest dan postest yang diberikan kepada kelas eksperimen dan kelas kontrol menggunakan instrumen yang sama. Tes sebelum pembelajaran diberikan berupa materi operasi pada persamaan linier, sedangkan tes sesudah pembelajaran diberikan berupa materi fungsi invers.

Teknik analisis data yang digunakan dalam penelitian adalah statistik deskriptif. Data penelitian dianalisis dengan menggunakan uji ttest. Data analisis akan mempresentasikan hasil belajar fungsi invers siswa antara kelas kelas eksperimen dan kelas kontrol.

\section{HASIL DAN PEMBAHASAN}

Data kuantitatif diperoleh melalui tes hasil belajar mahasiswa di awal dan di akhir pembelajaran, mahasiswa yang melakukan tes hasil belajar sebanyak 64 orang mahasiswa, yang meliputi 32 orang mahasiswa yang berasal dari kelas eksperimen dan 32 orang mahasiswa berasal dari kelas kontrol. Sebelum dilakukan tindakan kedua kelompok (eksperimen dan kontrol) dilakukan pengujian persyaratan data. 
DOI: https://doi.org/10.24127/ajpm.v9i1.2666

Dari hasil penelitian yang diperoleh dari pengujian persyaratan data dapat diketahui bahwa kelas eksperimen dan kelas kontrol merupakan kelas yang normal, homogen, dan memiliki taraf kepercayaan yang layak untuk dijadikan sampel penelitian.

Tabel 1. Hasil Uji Normalitas N-Gain Hasil Belajar.

\begin{tabular}{lcccccccc}
\hline & \multirow{8}{c}{ Tests of Normality } \\
\hline \multirow{2}{*}{ Faktor } & \multicolumn{1}{c}{ Kolmogorov-Smirnov ${ }^{\boldsymbol{a}}$} & \multicolumn{3}{c}{ Shapiro-Wilk } \\
\cline { 2 - 8 } & Statistic & $\boldsymbol{d f}$ & Sig. & Statistic & $\boldsymbol{d f}$ & Sig. \\
\hline \multirow{2}{*}{ Hasil Belajar Eksperimen } & .118 & 31 & .084 & .915 & 31 & .032 \\
\cline { 2 - 8 } & Kontrol & .105 & 31 & .132 & .922 & 31 & .163 \\
\hline
\end{tabular}

a. Lilliefors Significance Correction, $\alpha=0,05$

Hasil analisis data awal berkenaan dengan hasil tes persamaan linier sebagai apersepsi mata materi fungsi invers, dengan menggunakan Kolmogorov-Smirnov dan Shapiro-Wilk pada Tabel 1 dapat diketahui bahwa kelas eksperimen memiliki nilai

Tabel 2. Independent Samples Test signifikansi $\mathrm{p}=0,032>\alpha=0,05$, dan hasil pada kelas kontrol memiliki nilai signifikansi $\mathrm{p}=0,163>\alpha=0,05$. Hasil analisis pada Tabel 1 bahwa sampel berasal dari populasi yang berdistribusi normal.

\begin{tabular}{cccccccc}
\hline & $\boldsymbol{F}$ & Sig. & $\boldsymbol{t}$ & $\boldsymbol{d f}$ & $\begin{array}{c}\text { Sig. } \\
(2-t a i l e d)\end{array}$ & $\begin{array}{c}\text { Std. Error } \\
\text { Difference }\end{array}$ \\
\hline \multirow{2}{*}{ Hasil } & $\begin{array}{c}\text { Equal variances } \\
\text { assumed }\end{array}$ & .59 & .44 & 7.68 & 78 & .003 & .0293 \\
\cline { 2 - 4 } & $\begin{array}{c}\text { Equal variances } \\
\text { not assumed }\end{array}$ & & & 7.68 & 76.16 & .005 & .0249 \\
\hline
\end{tabular}

Dari Tabel 2 diketahui bahwa $p$ value sebesar $0,003<0,005$ sehingga diperoleh bahwa terdapat perbedaan yang signifikan dengan probabilitas sebesar 0,05 pada hasil belajar fungsi invers antara mahasiswa pada kelas eksperimen dan siswa pada kelas kontrol. Pembelajaran matematika pada fungsi invers dengan menggunakan model think pair share berbantuan maple secara empiris terbukti dapat meningkatkan pemahaman mahasiswa pada materi fungsi invers.

Berdasarkan data penelitian
diperoleh bahwa hasil belajar
mahasiswa pada materi fungsi invers
dengan menggunakan model
pembelajaran think pair share
berbantuan maple lebih baik dari
pembelajaran dengan menggunakan
model pembelajaran student team
achievement division dikarenakan siswa
yang menggunakan model pembelajaran
think pair share berbantuan maple lebih
leluasa dalam berdiskusi dengan sesama
kelompoknya. Dengan menggunakan
model pembelajaran think pair share,
mahasiswa lebih interaktif dalam

$\begin{array}{rrr}\text { Berdasarkan } & \text { data penelitian } \\ \text { diperoleh bahwa hasil } & \text { belajar }\end{array}$ mahasiswa pada materi fungsi invers dengan menggunakan model pembelajaran think pair share berbantuan maple lebih baik dari pembelajaran dengan menggunakan model pembelajaran student team achievement division dikarenakan siswa yang menggunakan model pembelajaran think pair share berbantuan maple lebih leluasa dalam berdiskusi dengan sesama kelompoknya. Dengan menggunakan mahasiswa lebih interaktif dalam 
kelompoknya. Kondisi ini terjadi dikarenakan langkah-langkah proses pembelajaran yang lebih jelas dan terarah. Hal ini juga didukung oleh hasil penelitian (Kusuma \& Maskuroh, 2018; Panjaitan, 2019) yang menyatakan bahwa menggunakan model pembelajaran think pair share membuat siswa aktif bahkan mampu menghubungkan materi pembelajaran dengan kehidupan nyata.

Aturan dan langkah yang digariskan pembelajaran think pair share mampu membuat mahasiswa lebih kondusif dalam proses berdiskusi dan pembelajaran. Pembentukan kelompok/pasangan dalam pembelajaran membuat proses diskusi lebih baik dari model pembagian kelompok yang diterapkan pada model pembelajaran student team achievement division. Selain hal tersebut, proses berpikir dalam sistematika think pair share membuat proses pembelajaran lebih terarah. Dalam proses diskusi pada model pembelajaran student teams achievement divison tidak mengatur secara rinci langkah-langkah di dalam diskusi. Kondisi ini membuat mahasiswa berdiskusi tanpa teknik yang baik. Mahasiswa hanya berdiskusi untuk memperoleh penyelesaian dari soal yang diberikan tanpa memahami cara berdiskusi dengan baik.

Penggunaan maple dalam proses pembelajaran juga berpengaruh sangat signifikan. Penggunaan maple membuat mahasiswa merasa memiliki pendamping belajar sebagai acuan dalam memeriksa hasil akhir penyelesaian soal. Langkah-langkah penyelesaian yang diberikan oleh maple mambuat mahasiswa lebih tertuntut dalam memeriksa hasil pengerjaan soal. Maple dapat menggantikan guru sebagai korektor dalam penyelesaian soal matematika. Temuan ini senada dengan beberapa penelitian tentang penggunaan maple yang dapat meningkatkan hasil belajar. (Razi \& Mirunnisa, 2019; Saparwadi \& Yuwono, 2019; Sapta, 2018)

\section{KESIMPULAN DAN SARAN}

Berdasarkan hasil penelitian diperoleh kesimpulan bahwa pembelajaran matematika pada fungsi invers dengan menggunakan model think pair share berbantuan maple secara empiris terbukti dapat meningkatkan pemahaman mahasiswa pada materi fungsi invers

Penggunaan aplikasi maple dalam pembelajaran dibutuhkan pemahaman dosen yang lebih mendalam, terutama saat terjadi trouble pada aplikasi. Kondisi ini dapat dijadikan refleksi bagi peneliti selanjutnya untuk mendapatkan hasil penelitian yang lebih baik.

\section{DAFTAR PUSTAKA}

Dahari, S., \& Hall, R. (2017). Relationship of Behavioural Intentions With Academic Knowledge Transfer Behaviour. International E-Journal of Advances in Social Sciences, 3(8), 707-712.

https://doi.org/10.18769/ijasos.337 937

Kusuma, A. P., \& Maskuroh, M. (2018). The Differences of Mathematics Learning Outcomes between Think Pair Share (TPS) and Number Heads Together (NHT). Al-Jabar: Jurnal Pendidikan Matematika, 9(1), 19. https://doi.org/10.24042/ajpm.v9i1. 2246

Laswadi. (2015). Pendekatan Problem Solving berbantuan Komputer dalam Pembelajaran Matematika. Al-Jabar: Jurnal Pendidikan 
DOI: https://doi.org/10.24127/ajpm.v9i1.2666

Matematika, 6(1), 33-41. https://doi.org/https://doi.org/10.24 042/ajpm.v6i1.59

Lestari, D. J., Samsuri, T., \& Adawiyah, S. R. (2017). Pengaruh Integrasi Model Pembelajaran Think-PairShare dengan Make A Match terhadap Aktivitas dan Hasil Belajar Siswa. Prisma Sains: Jurnal Pengkajian Ilmu Dan Pembelajaran Matematika Dan IPA IKIP Mataram, 5(2), 59. https://doi.org/10.33394/jps.v5i2.1159

Oktaviani, S., Santoso, B., \& Hiltrimartin, C. (2017). PENGGUNAAN POWERPOINT GAME PADA PEMBELAJARAN LINGKARAN DI KELAS VIII SMP NEGERI 1 TANJUNG RAJA. Jurnal Pendidikan Matematika, 11(1), 29-42. https://doi.org/https://doi.org/10.22 342/jpm.11.1.4131.29-42

Panjaitan, D. J. (2019). Model Think Pair Share dengan Media Aplikasi Komputer untuk Meningkatkan Penguasaan Triple Pythagoras. Jurnal MathEducation Nusantara, 2(2), 172-177. https://doi.org/https://doi.org/10.32 696/jmn.v2i2.91

Paryanti. (2015). Penerapan Model Cooperative Learning Tipe Think Pair Share Untuk Meningkatkan Aktivitas dan Hasil Belajar Matematika Siswa Kelas VI SD Negeri Kaliwadas 01. Aksioma: Jurnal Program Studi Pendidikan Matematika, 4(2), 72-83. https://doi.org/http://dx.doi.org/10. 24127/ajpm.v4i2.296

Pratama, R. A., \& Ismiyati, N. (2019). Pembelajaran Matematika Berbasis Edmodo Pada Mata Kuliah Teori Bilangan. Aksioma: Jurnal Program Studi Pendidikan
Matematika, 8(2), 298-309. https://doi.org/https://doi.org/10.24 127/ajpm.v8i2.2125

Razi, Z., \& Mirunnisa. (2019). Model Discovery Learning Berbantuan Software Maple Terhadap Kemampuan Pemahaman Matematis. Jurnal Program Studi Pendidikan Matematika, 8(3), 520-527.

https://doi.org/https://doi.org/10.24 127/ajpm.v8i3.2423

Saparwadi, L., \& Yuwono, T. (2019). Pembelajaran Kalkulus Berbantuan Sofware Maple: Studi Perbedaan Hasil Kerja Mahasiswa dengan Menggunakan Maple dan Tanpa Menggunakan Maple. Elemen, 5(1), 23-30. https://doi.org/10.29408/jel.v5i1.72 2

Sapta, A. (2018). Peningkatan Hasil Belajar Sukubanyak Melalui Model Pembelajaran Quiz Team Berbantuan Aplikasi Maple. Jurnal Mathematic Paedagogic, 2(2), 166. https://doi.org/10.36294/jmp.v2i2. 215

Sapta, A., Hamid, A., \& Syahputra, E. (2018). Assistance of Parents In The Learning At Home. Journal of Physics: Conference Series, 1114(1). $\quad$ https://doi.org/DOI: 10.1088/1742-6596/1114/1/012020

Sapta, A., Pakpahan, S. P., \& Sirait, S. (2019). Using The Problem Posing Learning Model Based on Open Ended to Improve Mathematical Critical Thinking Ability. Journal of Research in Mathematics Trends and Technology, 1(1), 13-17. https://doi.org/https://doi.org/10.32 734/jormtt.v1i1.752

Susanti, B., \& Lestari, Y. A. P. (2019). Analisis Kesulitan Siswa XI Dalam Menyelesaikan Soal Fungsi Komposisi dan Fungsi Invers di 
DOI: $\underline{\text { https://doi.org/10.24127/ajpm.v9i1.2666 }}$

SMK Al-Ikhsan Batujajar. Journal On Education, 01(03), 446-459. https://doi.org/Retrieved from http://www.jonedu.org/index.php/j oe/article/view/189

Tossavainen, T., \& Faarinen, E.-C. (2019). Swedish Fifth and Sixth Graders 'Motivational Values and the Use of ICT in Mathematics Education. Eurasia Journal of Mathematics, Science And Technology Education, 15(12), em1776.

https://doi.org/https://doi.org/10.29 333/ejmste/108533

Yorulmaz, A., Altintas, S., \& Sidekli, S. (2017). Investigation of the Effects of Mathematical Thinking States of Form Teachers on Their Mathematics Teaching Anxieties. European Journal of Educational Research, 6(4), 485-493. https://doi.org/10.12973/eujer.6.4.485

Zuraida, D. A., \& Karyati, K. (2018). The effectiveness comparison problem based learning model with NHT and TPS type on plane solid figure. Jurnal Riset Pendidikan Matematika, 5(2), 254-263. https://doi.org/10.21831/jrpm.v5i2. 16444 